\title{
Medical Applications of Transforming Growth Factor- $\beta$
}

Kathleen C. Flanders, PhD, Laboratory of Cell Regulation and Carcinogenesis, National Institutes of Health, Bethesda, Maryland James K. Burmester, PhD, Personalized Medicine Research Center, Marshfield Medical Research Foundation, Marshfield, Wisconsin

\begin{abstract}
Transforming growth factor- $\beta$ (TGF- $\beta$ ) proteins and their antagonists have entered clinical trials. These multi-functional regulators of cell growth and differentiation induce extracellular matrix proteins and suppress the immune system making TGF- $\beta$ s useful in treatment of wounds with impaired healing, mucositis, fractures, ischemia-reperfusion injuries, and autoimmune disease. In diseases such as keloids, glomerulonephritis and pulmonary fibrosis, excessive expression of TGF- $\beta$ has been implicated as being responsible for accumulation of detrimental scar tissue. In these conditions, agents that block TGF- $\beta$ have prevented or reversed disease. Similarly, in carcinogenesis, blocking TGF- $\beta$ activity may be valuable in stimulating an immune response towards metastasis. As these blocking agents receive approval, we will likely have new therapies for previously recalcitrant diseases.
\end{abstract}

REPRINT REQUESTS:

James K. Burmester, PhD

Personalized Medicine Research Center

Marshfield Medical Research Foundation

1000 North Oak Avenue

Marshfield, WI 54449

Telephone: $715-389-4368$

Fax: $715-389-3808$

Email: burmester.james@marshfieldclinic.org

\section{KEYWORDS:}

Fibrosis; Cancer; Immunosuppression; Knockout mice 


\section{TGF- $\beta$ SYNTHESIS}

Transforming growth factor- $\beta$ (TGF- $\beta$ ) is a family of related proteins that regulate many cellular processes including growth, differentiation, extracellular matrix formation and immunosuppression. ${ }^{1-4}$ TGF- $\beta$ protein is produced by nearly all normal cells and functions through a complex cell surface receptor system. ${ }^{5}$ The three mammalian isoforms of TGF- $\beta$ (TGF- $\beta$ s 1, 2, and 3 ) have similar but distinct functions and are approximately $70 \%$ identical in amino acid sequence. The TGF- $\beta$ s are extremely important in the regulation of physiological homeostasis with loss of TGF- $\beta$ activity being implicated in the pathogenesis of ovarian cancer, ${ }^{6}$ pancreatic cancer, ${ }^{7}$ colon cancer, ${ }^{8}$ and squamous cell carcinoma ${ }^{9}$ since TGF- $\beta$ is a potent growth inhibitor. Mutations preventing TGF- $\beta$ function are also causal for hereditary hemorrhagic telangiectasia, ${ }^{10}$ and corneal dystrophy. ${ }^{11}$ Over activity of TGF- $\beta$ leads to Camurati-Engelmann Disease of bone, ${ }^{12}$ glomerulonephritis, ${ }^{13}$ scar formation, ${ }^{14}$ keloids, ${ }^{15}$ pulmonary fibrosis, ${ }^{16}$ and liver cirrhosis. ${ }^{17}$

The TGF- $\beta$ proteins are synthesized as pre-pro-peptides which are secreted from cells in a primarily inactive form called latent TGF- $\beta^{18}$ consisting of a $25 \mathrm{kD}$ mature region surrounded by the pro region, which is also called the latency

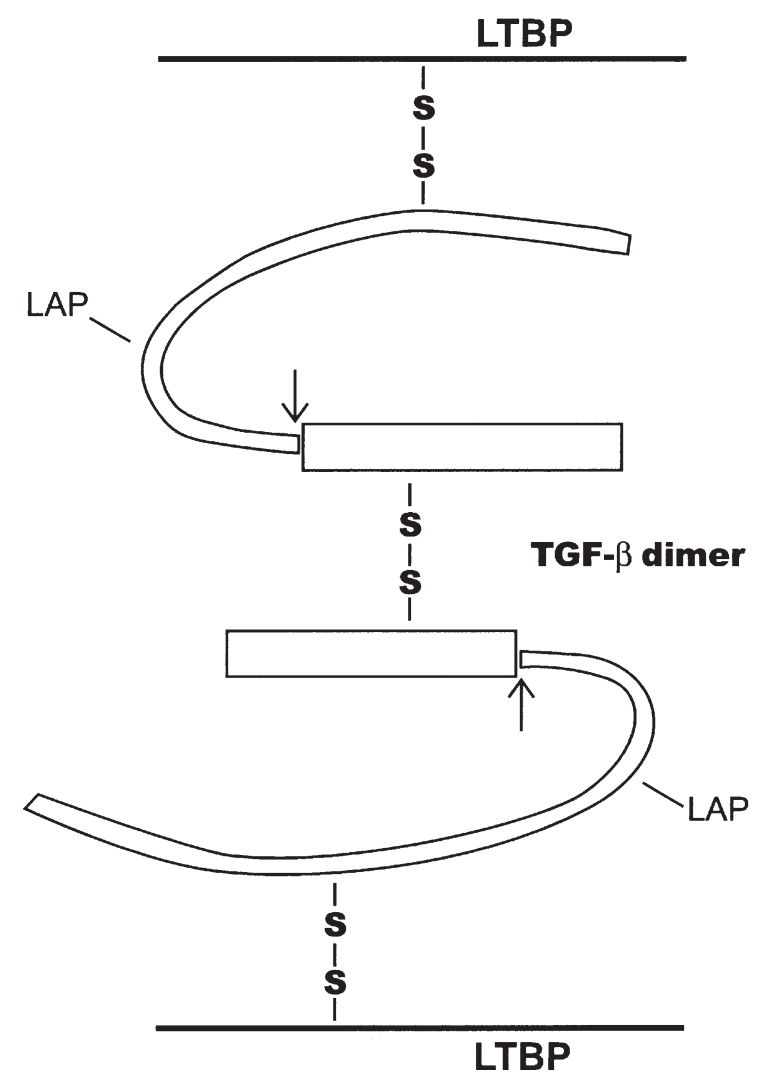

Figure 1. TGF- $\beta$ latency complex.

The structure of the inactive TGF- $\beta$ complex is shown with the TGF- $\beta$ dimer interacting with the latency associated peptide (LAP) and the latent TGF- $\beta$ binding protein (LTBP). Arrow indicates cleavage site. associated peptide (figure 1). Latent TGF- $\beta$ resides in the extracellular spaces between cells and is available for response to cellular stress or changes in physiology. Activation of TGF- $\beta$ cleaves the pro region and separates the latency peptide from the active molecule in a highly regulated manner. Agents known to activate TGF- $\beta$ include, acidic microenvironments, plasmin, plasmin-like proteases, and $\alpha v \beta 6$ integrin.

The structure of TGF- $\beta$ has been determined using a combination of nuclear magnetic resonance and x-ray crystal diffraction (figure 2). ${ }^{19-24}$ Amino acids 45 and 47 interact with $\alpha_{2}$-macroglobulin, an abundant serum protein that binds and inactivates TGF- $\beta .25,26$ Amino acids 67 and 68 determine the affinity of the TGF- $\beta$ isoforms for the GPI-linked protein on vascular endothelial cells. ${ }^{27}$ Amino acids $92-98$ regulate binding of TGF- $\beta$ to the TGF- $\beta$ type II receptor (T $\beta$ RII), ${ }^{28}$ with amino acid 94 directly binding T $\beta$ RII. ${ }^{29,30}$

\section{SIGNALING PATHWAYS}

TGF- $\beta$ signals through a complex membrane bound receptor and binding protein system ${ }^{31,32}$ which can include $\beta$-glycan, ${ }^{33}$ the type I and II receptors, ${ }^{34}$ endoglin, ${ }^{35}$ an uncharacterized glycosyl phosphatidylinositol-linked protein, ${ }^{36}$ and BAMBI, a naturally occurring truncated type I receptor. ${ }^{37}$ Both endoglin and $\beta$-glycan can present TGF- $\beta$ to the type II receptor which complexes with and phosphorylates the type I receptor. The type I (TRRI) and II (T $\beta R I I)$ receptors are transmembrane serine/threonine specific kinases with T $\beta R I$ interacting with and phosphorylating intracellular molecules. Intracellular signaling requires the Smad family of proteins in which Smad2 and Smad3 are directly phosphorylated by T $\beta R I$ and go on to form a complex with Smad4. 3,4,31,32 This complex directly enters the nucleus where it interacts with other transcription factors to regulate gene transcription. In contrast, Smad7 inhibits phosphorylation of Smad2 and Smad3 in a negative feedback loop preventing over-stimula-

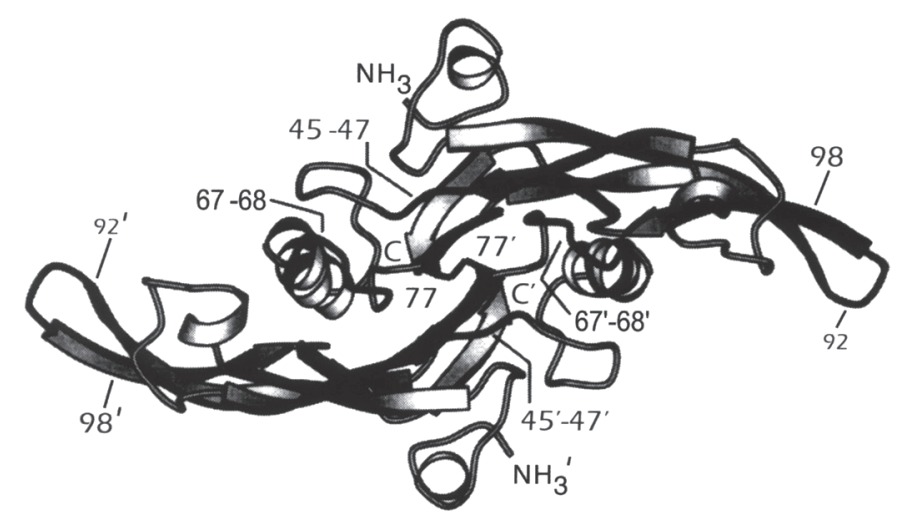

Figure 2. Structure of TGF- $\beta$.

The crystal structure of TGF- $\beta$ is shown. Amino acids important in regulating binding of TGF- $\beta$ to receptors and binding proteins have been highlighted. 
tion of the cell by TGF- $\beta$. TGF- $\beta$ signaling is further regulated by the interaction of Smad proteins with a variety of transcriptional activators and repressors ${ }^{38}$ as well as by complex interactions of the Smad and MAP kinase signaling pathways. 39

Through the use of microarray technology, much progress has been made in identifying the genes that are regulated by TGF- $\beta .40 \beta$ ig-h3 (TGF- $\beta$ induced gene), a secreted protein that inhibits tumor formation when overexpressed, is another important protein synthesized by cells in response to TGF- $\beta .41$

\section{TGF- $\beta$ AND DISEASE}

Mutations of TGF- $\beta$ or components of its signal pathway are frequently found in disease (table 1). Patients with CamuratiEngelmann have a missense mutation in the latency associated peptide which changes one of three different amino acids, producing constitutively active TGF- $\beta .^{12,42}$ This results in disregulation of TGF- $\beta$ synthesis, uncoupling bone formation and resorption at the level of the osteoblasts and osteoclasts.

Mutations of $\beta$ ig-h3, a protein involved in corneal morphogenesis, have been identified as a cause of six autosomal dominant corneal dystrophies. These include Groenouw corneal dystrophy type I, superficial variant of granular corneal dystrophy, lattice corneal dystrophy type I, lattice corneal dystrophy type IIIA, Avellino corneal dystrophy, and Reis-Bucklers corneal dystrophy. ${ }^{43}$ It appears that mutant ßig-h3 protein self-polymerizes and/or incorrectly binds to other corneal components resulting in the abnormal deposits found in these dystrophies. ${ }^{44}$

Hereditary hemorrhagic telangiectasia (HHT) type 1 or OslerWeber-Rendu disease is caused by mutations of endoglin. ${ }^{10}$ In HHT type II, mutations of activin receptor-like kinase 1 (ALK1) have been identified. ${ }^{45}$ ALK1, a membrane bound receptor that is closely related to T $\beta$ RI, binds TGF- $\beta$ and signals a TGF- $\beta$ response. However, the preferred ligand for ALK1 is activin, a protein structurally similar to TGF- $\beta$, but distinct in its function. In both types of HHT, the endothelial

Table 1. Genetic diseases of the TGF- $\beta$ system.

\begin{tabular}{ll}
\hline Camurati-Engelmann & Latency associated peptide \\
Corneal dystrophies & Big-h3 \\
$\begin{array}{l}\text { Hereditary hemorrhagic } \\
\text { telangiectasis type I } \\
\begin{array}{l}\text { Hereditary hemorrhagic } \\
\text { telangiectasis type II }\end{array}\end{array}$ & Endoglin \\
$\begin{array}{l}\text { Autosomal dominant } \\
\text { juvenile polyposis }\end{array}$ & $\begin{array}{l}\text { Smad4 bone morphogenetic } \\
\text { protein receptor I }\end{array}$ \\
\hline
\end{tabular}

cells would be expected to respond poorly to TGF- $\beta$, which could contribute to the abnormal vessel formation or altered cell adhesion properties leading to the vascular anomalies seen in this disorder.

Mutations of Smad4 have been identified as the cause of familial autosomal dominant juvenile polyposis in a subset of patients. ${ }^{46}$ Other families with this disease carry mutations in the gene encoding bone morphogenetic protein receptor $1^{47}$ which is a membrane bound receptor similar to T $\beta R I$. The preferred ligand for this mutated receptor is bone morphogenetic protein, a protein similar to TGF- $\beta$ with growth regulating activity. T $\beta$ RII mutations have been identified in approximately $90 \%$ of colon polyps with DNA repair defects $^{48}$ and $70 \%$ of gastric cancers ${ }^{49}$ with repair defects. In these patients, DNA replication errors occur due to mutations in the genes that check the copied strand of DNA for mistakes. As a result, inactivating mutations accumulate in a stretch of 10 adenine bases in T $\beta$ RII, since the replication machinery does not carefully check this repetitive sequence. Additionally, deletion or inactivation of Smad4 has been shown in $30-50 \%$ of colorectal and pancreatic cancers. ${ }^{7,50}$ In all these conditions a disruption in the TGF- $\beta$ signaling pathway compromises the cell's ability to respond to the growth inhibitory effects of TGF- $\beta$, thereby promoting tumorigenesis.

\section{TGF- $\beta$ KNOCKOUT MICE}

Mice lacking the gene for the TGF- $\beta$ s or their regulatory and signaling proteins have been generated using homologous recombination and the role of TGF- $\beta$ in development and disease has been studied. Approximately $60 \%$ of mice lacking TGF- $\beta 1$ die in utero due to defective yolk sac vasculogenesis and hematopoiesis, which is consistent with the role of TGF- $\beta$ in embryogenesis. This defect is due to inappropriate endothelial cell differentiation. ${ }^{51}$ The remaining mice develop to term, but die in about week 3 to 4 from a rapid wasting syndrome. ${ }^{52,53}$ At birth, the knockout mice are indistinguishable from wild type litter mates, but soon develop severe, multifocal organ-dependent mixed inflammatory cell infiltration into heart, stomach, liver, diaphragm, lung, salivary gland and pancreas. These mice also have elevated antibody levels to dsDNA, ssDNA, and Sm ribonuclear protein. ${ }^{54}$ Treatment of these mice with anti-inflammatory and immune suppressive agents such as rapamycin reduces the severity of inflammation. In addition to immune system defects, the mice that are born experience delayed wound healing, 55 ineffective remodeling of bone, ${ }^{56}$ and increased mitochondria in the liver in response to stress. 57

TGF- $\beta 2$ knockout mice exhibit primarily developmental defects in contrast to TGF- $\beta 1$ mice. ${ }^{58}$ These include defects in epithelial-mesenchymal interactions, cell growth, extracellular matrix production and tissue remodeling, and affect the function of cardiac, lung, craniofacial, limb, spinal column, eye, inner ear and urogenital tissues. Analysis of eyes of 
TGF- $\beta 2$ knockout mice show that extracellular matrix proteins, including collagen I and keratocan, are diminished and the stroma is thinner. ${ }^{59}$ TGF- $\beta 3$ deficient mice also exhibit disruptions in epithelial-mesenchymal interactions as evidenced by the appearance of abnormal lung development and cleft palate. ${ }^{60}$ Unlike other models of cleft palate, these mice do not develop other craniofacial abnormalities.

Mice with deletions of genes in various components of the TGF- $\beta$ signaling pathway develop additional pathological phenotypes. T $\beta R I$ mice die at mid-gestation exhibiting defects in vascular development of the yolk sac and placenta with absence of red blood cells. ${ }^{61}$ T $\beta$ RII mutants developed pituitary tumors when treated with chronic estradiol. ${ }^{62}$ Mice lacking Smad3 live until 8 months and die of defects in immune function. ${ }^{63}$ These mice also have an imbalance between osteoblasts and osteoclasts resulting in osteopenia 63 and accelerated healing of cutaneous incisional wounds. ${ }^{64}$ Exposure of these mice to radiation-induced injury causes significantly less epidermal acanthosis and dermal influx of mast cells, macrophages, and neutrophils than wild type littermates, demonstrating that these mice have a significantly reduced fibrotic response. ${ }^{65} \mathrm{Smad} 4$ mice present with inflammatory polyps in the glandular stomach and duodenum consistent with previous reports that Smad4 mutations are involved in a subset of familial juvenile polyposis. ${ }^{66}$

\section{POSSIBLE USE OF TGF- $\beta$ LIGANDS FOR THERAPEUTIC INTERVENTION}

The well-characterized abilities of TGF- $\beta$ to promote healing in both hard and soft tissues, as well as its potent immunosuppressive effects, have provided the basis for the use of TGF- $\beta$ ligands as potential therapeutic agents in several disease models. Topical application of TGF- $\beta$ improves the rate of healing and wound strength in cutaneous wounds in a wide variety of animal models of impaired healing including animals treated with corticosteroids, antineoplastic agents, or radiation, as well as diabetic or aged animals. ${ }^{67}$ In clinical trials TGF- $\beta 2$ and TGF- $\beta 3$ treatment of venous stasis and pressure ulcers, respectively, has been shown to improve healing. ${ }^{68,69}$ In a hamster model of chemotherapy-induced oral mucositis, application of TGF- $\beta 3$ reduces the severity and duration of the resulting mucositis, ${ }^{70}$ and clinical trials of TGF- $\beta 3$ to treat this condition are underway. ${ }^{71}$ TGF- $\beta$ has also been shown to accelerate the repair of bone defects. In canine models, both TGF- $\beta 1$ and TGF- $\beta 2$ have been effective in increasing bone formation when applied to defects in the alveolar ridge and in the humerus, respectively. ${ }^{72,73}$ In keeping with its healing properties, TGF- $\beta$ also can protect tissues from ischemia-reperfusion injury in several animal models. In rat and rabbit models of stroke, administration of TGF- $\beta$ before or even $2 \mathrm{~h}$ after insult reduces the infarct size, ${ }^{74}$ while intravenous administration of TGF- $\beta$ following coronary artery occlusion, but before reperfusion reduces cardiac necrosis. ${ }^{75,76}$ Recent studies are investigating improved delivery systems for TGF- $\beta$. Pang et al. ${ }^{77}$ report that mice receiving adenovirus overexpressing TGF- $\beta 1$ showed a smaller infarct volume after middle cerebral artery occlusion followed by reperfusion.

The potent immunosuppressive effects of TGF- $\beta$ make it a potential therapeutic agent in the treatment of autoimmune diseases. Indeed, treatment of rodents with TGF- $\beta 1$ during the latter part of the induction phase of acute experimental allergic encephalomyelitis (EAE) (a model of multiple sclerosis) and collagen-induced arthritis prevents the development and/or exacerbation of disease symptoms. ${ }^{78,79}$ Again, novel delivery systems for administration of TGF- $\beta$ are being developed. A genetically engineered retrovirus transduced with cDNA for latent TGF- $\beta$ delays and ameliorates EAE development, ${ }^{80}$ and intranasal administration of a TGF- $\beta 1$ plasmid prevents the development of $\mathrm{T}$ helper cell type 1mediated experimental colitis. ${ }^{81}$ Additionally, intramuscular injections of adenoviral TGF- $\beta 1$ into rodent recipients of lung transplants attenuates acute rejection. ${ }^{82}$

\section{ANTAGONISTS OF TGF- $\beta$ FOR DISEASE TREATMENT}

Even though TGF- $\beta$ has great potential as a therapeutic agent, there are a number of fibroproliferative disorders where unregulated expression of TGF- $\beta$ plays a causal role in the condition. Numerous immunohistochemical studies have demonstrated the overexpression of TGF- $\beta$ in glomerulonephritis, pulmonary fibrosis, liver cirrhosis, and keloids suggesting that molecules that antagonize TGF- $\beta$ may be useful in the treatment of these diseases. ${ }^{83}$ In addition, since many tumors express increased amounts of TGF- $\beta$, agents that block TGF- $\beta$ may be valuable in stimulating an immune response toward metastases. ${ }^{84}$ Mechanisms to block TGF- $\beta$ activity include soluble T $\beta$ RII fragments, ${ }^{85}$ decorin, ${ }^{86}$ tranilast, ${ }^{87}$ neutralizing antibodies, ${ }^{88}$ threonine kinase inhibitors, ${ }^{89}$ and RNA expression inhibitors such as anti-sense expression vectors or blocking oligonucleotides. 90

Impressive results have been obtained in animal models of fibrosis using TGF- $\beta$ antagonists. Glomerulonephritis in rats has been essentially cured using antibodies to TGF- $\beta,{ }^{91}$ administration of decorin protein, ${ }^{92}$ and gene therapy using a decorin gene expressed in muscle tissue that circulates to act on kidney. ${ }^{13}$ Moreover, anti-TGF- $\beta 2$ antibody and a TGF- $\beta 1$ antisense oligonucleotide attenuate kidney fibrosis in the diabetic rat and in unilateral ureteral obstructions, respectively. ${ }^{88,93}$ Hepatic fibrosis in rodents can be inhibited by soluble T $\beta$ RII administered intraperitoneally ${ }^{94}$ or by intramuscular injections of an adenovirus expressing the ectodomain of T $\beta$ RII fused to the Fc portion of IgG. ${ }^{95}$ Adenoviral soluble T $\beta$ RII can also inhibit constrictive remodeling after coronary angioplasty in pigs. ${ }^{96}$ Pulmonary fibrosis has been successfully treated using adenovirus expression of decorin in the airway. ${ }^{86}$ Administration of TGF- $\beta$ antibodies prevents skin and lung fibrosis in murine sclerodermatous graft-vs-host 
disease. ${ }^{97}$ Fibrotic scar tissue is successfully treated using antibodies to TGF- $\beta 1$ or antibodies to TGF- $\beta 2$, but paradoxically, topical application of TGF- $\beta 3$ protein. ${ }^{14}$ Both decorin 98 and TGF- $\beta$ antibodies ${ }^{99}$ attenuate gliotic scar formation following injury to the rat CNS. In a mouse model of intestinal radiation enteropathy, intraperitoneal injection of soluble T $\beta$ RII preserves mucosal surface area with less intestinal wall fibrosis than in controls. ${ }^{100}$ Mice injected intramuscularly with an adenovirus vector expressing the soluble extra-cellular TGF- $\beta$ binding domain of T $\beta$ RII are protected from developing corneal opacification, edema, and angiogenesis induced by silver nitrate. ${ }^{85}$

Several rodent carcinogenesis models have demonstrated the efficacy of TGF- $\beta$ antagonists to inhibit tumor growth and metastasis. Antisense oligonucleotides to TGF- $\beta 2$ inhibit the growth of mouse malignant melanomas ${ }^{84}$ and

fibrosarcomas. ${ }^{101}$ TGF- $\beta$ antibody inhibits metastasis of tumorigenic human xenotransplants in nude mice, ${ }^{102}$ while ectopic expression of decorin in rat C6 glioma cells inhibits tumor formation. ${ }^{103}$ Furthermore, oral administration of tranilast, an anti-allergic compound which can inhibit TGF- $\beta$, inhibits the growth of experimental 9L rat gliomas. ${ }^{104} \mathrm{~A}$ phase I clinical trial of TGF- $\beta$ antagonists for the treatment of metastatic cancer is currently in progress. ${ }^{105}$ In this trial, autologous tumor cells are removed from patients and treated in vitro with TGF- $\beta 2$ anti-sense DNA to suppress TGF- $\beta$ expression from tumor cells. This treatment blocks the immunosuppressive activity of TGF- $\beta$ enhancing immune system recognition of tumor cells. TGF- $\beta 2$ blocked cells are then injected back into the patient as antigens for the immune system. Five patients with progressive glioblastoma multiform and one with progressive gliosarcoma are enrolled in the trial and treated with 2 to 7 subcutaneous injections of approximately $1 \times 10^{7}$ modified tumor cells. TGF- $\beta$ levels were decreased by 50\%-98\%. Two patients had partial regressions and one patient had stable disease following therapy supporting further clinical evaluation of TGF- $\beta$ modified anti-sense tumor cells for treatment of incurable metastatic disease.

\section{THERAPEUTIC APPLICATIONS: PROBLEMS AND PERSPECTIVES}

The preceding sections highlight the many types of diseases in which alterations in the TGF- $\beta$ signaling pathway may have pathological consequences. While restoration of the proper flux through the pathway by administration of either ligand or antagonists may alleviate the pathology, accomplishing this in only the affected tissue or cell type will be difficult. Normal homeostatic actions of TGF- $\beta$ in uncompromised cells may also be altered by treatment agents leading to unwanted and unexpected complications. The pleiotropic actions of TGF- $\beta$ are illustrated by its role in carcinogenesis, where TGF- $\beta$ can have tumor suppressor, as well as prooncogenic activities. ${ }^{106}$ TGF- $\beta$ normally inhibits growth of epithelial cells, but tumorigenesis is often accompanied by a loss of responsiveness to this growth inhibition coupled with increased production of TGF- $\beta$, which in turn facilitates prooncogenic effects of TGF- $\beta$ on stroma. These effects can include increased cell motility, enhanced angiogenesis and suppression of immune surveillance. An ideal treatment for cancer would involve restoring TGF- $\beta$ signaling in epithelial cells and inhibiting its action in stromal cells, necessitating the development of cell type specific delivery systems.

Since the mode of delivery of TGF- $\beta$ ligand or antagonist will be critical in affecting only the desired system, local, as opposed to systemic, delivery is probably preferable. For example, in a phase I trial for treatment of chronic progressive multiple sclerosis, intravenous administration of active TGF- $\beta 2107$ resulted in anemia and reversible nephrotoxicity in some patients with no change in expanded disability status score of magnetic resonance imaging lesions during treatment. In contrast, murine experimental allergic encephalomyelitis was ameliorated by administration of myelin basic protein-activated $\mathrm{T}$ cells transduced with latent TGF- $\beta 1.80$ In this regard administration of adenoviral vectors of TGF- $\beta$ or TGF- $\beta$ antagonists is being widely used in animal models. ${ }^{13,77,81,95,96}$ The administration of active-vs.latent TGF- $\beta$ is also an important consideration. Active TGF$\beta$ has a much shorter half-life than the latent form, ${ }^{108}$ and active TGF- $\beta$ may result in more side effects, since it is not subject to the activation step which is tightly controlled in vivo. Additional complications of administration of active TGF- $\beta$ are its reported inactivation by proteases present in wound fluid from venous leg ulcers. ${ }^{109}$ This proteolytic degradation of ligand may have contributed to the inefficacy of topical TGF- $\beta 3$ in treating chemotherapy-induced oral mucositis in patients with lymphomas and solid tumors. ${ }^{71}$

In spite of these problems, some current clinical modalities may be acting by decreasing TGF- $\beta$ signaling. The success of angiotensin-converting-enzyme inhibitors in treating diabetic nephropathy, interferon- $\alpha$ in treating hepatic fibrosis, azathioprine and prednisone in treating autoimmune hepatitis, and interferon- $\gamma$ in treating pulmonary fibrosis is due, in part, to the ability of these agents to reduce serum levels of TGF- $\beta .{ }^{110}$ The search for small molecules that target the TGF- $\beta$ system is currently underway using combinatorial chemistry and high-throughput drug screening.

\section{CONCLUSION}

TGF- $\beta$ and its antagonists have tremendous potential for the treatment of diseases that currently do not respond well to conventional therapy. The development of additional analogs of TGF- $\beta$ and antagonists of TGF- $\beta$, as well as further studies into the cell biology of this important cytokine, may enable us to develop new therapeutics. 


\section{REFERENCES}

1. Roberts $\mathrm{AB}$, Sporn MB. The transforming growth factor- $\beta$ s. In: Sporn $\mathrm{MB}$, Roberts AB, editors. Peptide Growth Factors and Their Receptors. Handbook of Experimental Pharmacology. Vol. 1, Chapter 8, Berlin, Heidelberg: Springer, 1995, p. 419-472.

2. Massagué J. The transforming growth factor- $\beta$ family. Annu Rev Cell Biol 1990;6:597-641.

3. Ten Dijke P, Goumans MJ, Itoh F, Itoh S. Regulation of cell proliferation by Smad proteins. J Cell Physiol 2002;191:1-16.

4. Verrecchia F, Mauviel A. Transforming growth factor- $\beta$ signaling through the Smad pathway: Role in extracellular matrix gene expression and regulation. J Invest Dermatol 2002;118:211-215.

5. Massagué J, Blain SW, Lo RS. TGF- $\beta$ signaling in growth control, cancer, and heritable disorders. Cell 2000;103:295-309.

6. Wang D, Kanuma T, Mizunuma H, Takama F, Ibuki Y, Wake N, Mogi A, Shirtara Y, Takenoshita S. Analysis of specific gene mutations in the transforming growth factor- $\beta$ signal transduction pathway in human ovarian cancer. Cancer Res 2000;60:4507-4512.

7. Hahn SA, Schutte M, Hoque AT, Moskaluk CA, da Costa LT, Rozenblum E, Rozenblum E, Weinstein CL, Fischer A, eo CJ, Hruban RH, Kern SE. DPC4, a candidate tumor suppressor gene at human chromosome 18q21.1. Science 1996;271:350-353.

8. Markowitz S, Wang J, Myeroff L, Parsons R, Sun L, Lutterbaugh J, Fan RS, Zborowska E, Kinzler KW, Vogelstein B. Inactivation of the type II TGF- $\beta$ receptor in colon cancer cells with microsatellite instability. Science 1995;268:1336-1338.

9. Garrigue-Antar L, Muñoz-Antonia T, Antonia SJ, Gesmonde J, Vellucci VF, Reiss M. Missense mutations of the transforming growth factor $\beta$ type II receptor in human head and neck squamous carcinoma cells. Cancer Res 1995;55:3982-3987.

10. McAllister KA, Grogg KM, Johnson DW, Gallione CJ, Baldwin MA, Jackson CE, Helmbold EA, Markel DS, McKinnon WC, Murrell J, et al. Endoglin, a TGF- $\beta$ binding protein of endothelial cells, is the gene for hereditary haemorrhagic telangiectasia type 1 . Nat Genet 1994;8:345-351.

11. Mashima Y, Yamamoto S, Inoue Y, Yamada M, Konishi M, Watanabe H, Maeda N, Shimomura Y, Kinoshita S. Association of autosomal dominantly inherited corneal dystrophies with Big-h3 gene mutations in Japan. Am J Ophthalmol 2000;130:516-517.

12. Saito T, Kinoshita A, Yoshiura Ki, Makita Y, Wakui K, Honke K, Niikawa $\mathrm{N}$, Taniguchi N. Domain-specific mutations of a transforming growth factor-(TGF) $\beta 1$ latency-associated peptide cause Camurati-Englemann disease because of the formation of a constitutively active form of TGF-ß1. J Biol Chem 2001;276:11469-11472.

13. Isaka Y, Brees DK, Ikegaya K, Kaneda Y, Imai E, Noble NA, Border WA. Gene therapy by skeletal muscle expression of decorin prevents fibrotic disease in rat kidney. Nat Med 1996;2:418-423.

14. Shah M, Foreman DM, Ferguson MWJ. Neutralisation of TGF- $\beta 1$ and TGF- $\beta 2$ or exogenous addition of TGF- $\beta 3$ to cutaneous rat wounds reduces scarring. J Cell Sci 1995;108:985-1022.

15. Lee TY, Chin GS, Kim WJ, Chau D, Gittes GK, Longaker MT. Expression of transforming growth factor $\beta 1,2$, and 3 proteins in keloids. Ann Plast Surg 1999;43:179-184.

16. Khalil N, Greenberg AH. The role of TGF- $\beta$ in pulmonary fibrosis. Ciba Found Symp 1991;157:194-207.

17. Castilla A, Prieto J, Fausto N. Transforming growth factors $\beta 1$ and $\alpha$ in chronic liver disease. N Engl J Med 1991;324:933-940.

18. Lawrence DA. Latent-TGF- $\beta$ : an overview. Mol Cell Biochem 2001;219:163-170

19. Daopin S, Li M, Davies DR. Crystal structure of TGF- $\beta 2$ refined at 1.8 A resolution. Proteins 1993;17:176-192.

20. Archer SJ, Bax A, Roberts AB, Sporn MB, Ogawa Y, Piez KA, Weatherbee JA, Tsang ML, Lucas R, Zheng Bl, et al. Transforming growth factor- $\beta 1$ : NMR signal assignments of the recombinant protein expressed and isotopically enriched using Chinese hamster ovary cells. Biochemistry 1993;32:1152-1163.

21. Daopin S, Piez KA, Ogawa Y, Davies DR. Crystal structure of transforming growth factor- $\beta 2$. An unusual fold for the superfamily. Science 1992;257:369-373
22. Hinck AP, Archer SJ, Qian SW, Roberts AB, Sporn MB, Weatherbee JA, Tsang ML, Lucas R, Zhang BL, Wenker J, Torchia DA. Transforming growth factor- $\beta 1$ : Three-dimensional structure in solution and comparison with the X-ray structure of transforming growth factor- $\beta 2$. Biochemistry 1996;35:8517-8534.

23. Mittl PRE, Priestle JP, Cox DA, McMaster G, Cerletti N, Grutter MC. The crystal structure of TGF- $\beta 3$ and comparison to TGF- $\beta 2$ : Implications for receptor binding. Protein Sci 1996;5:1261-1271.

24. Schlunegger MP, Grutter MC. An unusual feature revealed by the crystal structure at $2.2 \mathrm{~A}$ resolution of human transforming growth factor- $\beta 2$. Nature 1992;358:430-434.

25. Burmester JK, Qian SW, Roberts AB, Huang A, Amatayakul-Chantler S, Suardet L, Odartchenko N, Madri JA, Sporn MB. Characterization of distinct functional domains of transforming growth factor- $\beta$. Proc Natl Acad Sci 1993;90:8628-8632.

26. Webb DJ, Atkins TL, Crookston KP, Burmester JK, Qian SW, Gonias SL. Transforming growth factor- $\beta$ isoform 2 -specific high affinity binding to native $\alpha_{2}$-macroglobulin. Chimeras identify a sequence that determines affinity for native but not activated $\alpha_{2}$ macroglobulin. J Biol Chem 1994;269:30402-30406.

27. Zhang KQ, Polga D, Salzman SA, Burmester JK. Amino acids 67 and 68 of TGF- $\beta$ regulate binding to a GPI-linked membrane protein on vascular endothelial cells. Cytokines Cell Mol Ther 2001 Mar;7(1):25-30.

28. Qian SW, Burmester JK, Tsang ML, Weatherbee JA, Hinck AP, Ohlsen DJ, Sporn MB, Roberts AB. Binding affinity of transforming growth factor- $\beta$ for its type II receptor is determined by the C-terminal region of the molecule. J Biol Chem 1996;271:30656-30662.

29. Burmester JK, Qian SW, Ohlsen D, Sporn MB, Roberts AB. Mutational analysis of a transforming growth factor- $\beta$ receptor binding site. Growth Factors 1998;15:231-242.

30. Hart PJ, Deep S, Taylor AB, Shu Z, Hinck CS, Hinck AP. Crystal structure of the human T $\beta R 2$ ectodomain - TG $\beta 3$ complex. Nat Struct Biol 2002;3:203-208.

31. Massague J. How cells read TGF-beta signals. Nat Rev Mol Cell Biol 2000;1:169-178

32. Dennler S, Goumans MJ, ten Dijke P. Transforming growth factor beta signal transduction. J Leukoc Biol 2002;15:731-740.

33. López-Casillas F, Wrana JL, Massagué J. Betaglycan presents ligand to the TGF- $\beta$ signaling receptor. Cell 1993;73:1435-1444.

34. Massagué J, Like B. Cellular receptors for type $\beta$ transforming growth factor. J Biol Chem 1985;260:2636-2645.

35. Cheifetz S, Bellón T, Calés C, Vera S, Bernabeu C, Massagué J, Letarte $\mathrm{M}$. Endoglin is a component of the transforming growth factor- $\beta$ receptor system in human endothelial cells. J Biol Chem 1992;267:19027-19030.

36. Morello JP, Plamondon J, Meyrick B, Hoover R, O'Connor-McCourt MD. Transforming growth factor- $\beta$ receptor expression on endothelial cells: Heterogeneity of type III receptor expression. J Cell Physiol 1995;165:201-211.

37. Onichtchouk D, Chen Y-G, Dosch R, Gawantka V, Delius H, Massagué J, Niehrs C. Silencing of TGF- $\beta$ signaling by the pseudoreceptor BAMBI. Nature 1999;401:480-485.

38. de Caestecker MP, Piek E, Roberts AB. Role of transforming growth factor-beta signaling in cancer. J Natl Cancer Inst 2000;92:1388-1402.

39. Yue J, Mulder KM. Transforming growth factor-beta signal transduction in epithelial cells. Pharmacol Ther 2001;91:1-34.

40. Akiyoshi S, Ishii M, Nemoto N, Kawabata M, Aburatani H, Miyazono K. Targets of transcriptional regulation by transforming growth factor- $\beta$ : Expression profile analysis using oligonucleotide arrays. Jpn J Cancer Res 2001;92:257-268.

41. Skonier J, Bennett K, Rothwell V, Kosowski S, Plowman G, Wallace P, Edelhoff S, Disteche C, Neubauer M, Marquardt H, et al. Big-h3: A transforming growth factor- $\beta$-responsive gene encoding a secreted protein that inhibits cell attachment in vitro and suppresses the growth of CHO cells in nude mice. DNA Cell Biol 1994;13:571-584.

42. Kinoshita A, Saito T, Tomita H, Makita Y, Yoshida K, Ghadami M, Yamada K, Kondo S, Ikegawa S, Nishimura G, Fukushima Y, Nakagomi T, Saito H, Sugimoto T, Kamegaya M, Hisa K, Murray JC, Taniguchi N, Niikawa N, Yoshiura K. Domain-specific mutations in TGF $\beta 1$ result in Camurati-Engelmann disease. Nat Genet 2000;26:1920.

43. Wrana JL, Attisano L, Carcamo J, Zentella A, Doody J, Laiho M, Wang XF, Massagué J. TGF beta signals through a heteromeric protein kinase receptor complex. Cell 1992;71;1003-1014. 
44. Streeten BW, Qi Y, Klintworth GK, Eagle RC Jr, Strauss JA, Bennett K. Immunocalization of $\beta$ ig-h3 protein in 5q31-linked corneal dystrophies and normal corneas. Arch Ophthalmol 1999;117:67-75.

45. Johnson DW, Berg JN, Baldwin MA, Gallione CJ, Marondel I, Yoon S-J, Stenzel TT, Speer M, Pericak-Vance MA, Diamond A, Guttmacher AE, Jackson CE, Attisano L, Kucherlapati R, Porteous ME, Marchuk DA. Mutations in the activin receptor-like kinase 1 gene in hereditary haemorrhagic telangiectasia type 2. Nat Genet 1996;13:189-195.

46. Howe JR, Roth S, Ringold JC, Summers RW, Järvinen HJ, Sistonen P, Tomlinson IP, Houlston RS, Bevan S, Mitros FA, Stone EM, Aaltonen LA. Mutations in the Smad4/DPC4 gene in juvenile polyposis. Science 1998;280:1086-1088.

47. Howe JR, Bair JL, Sayed MG, Anderson ME, Mitros FA, Petersen GM, Velculescu VE, Traverso G, Vogelstein B. Germline mutations of the gene encoding bone morphogenetic protein receptor $1 \mathrm{~A}$ in juvenile polyposis. Nat Genet 2001;28:184-187.

48. Parsons R, Myeroff LL, Liu B, Wilson JK, Markowitz SD, Kinzler KW, Vogelstein B. Microsatellite instability and mutations of the transforming growth factor $\beta$ Type II receptor gene in colorectal cancer. Cancer Res 1995;55:5548-5550.

49. Myeroff LL, Parsons R, Kim SJ, Hedrick L, Cho KR, Orth K, Mathis M, Kinzler KW, Lutterbaugh J, Park K, et al. A transforming growth factor- $\beta$ receptor type II gene mutation common in colon and gastric but rare in endometrial cancers with microsatellite instability. Cancer Res 1995;55:5545-5547.

50. Thiagalingam S, Lengauer C, Leach FS, Schutte M, Hahn SA Overhauser J, Wilson JK, Markowitz S, Hamilton SR, Kern SE, Kinzler KW, Vogelstein B. Evaluation of candidate tumour suppressor genes on chromosome 18 in colorectal cancers. Nat Genet 1996; 13:343-346.

51. Dickson MC, Martin JS, Cousins FM, Kulkarni AB, Karlsson S, Akhurst RJ. Defective haematopoiesis and vasculogenesis in transforming growth factor- $\beta 1$ knockout mice. Development 1995;121:1845-1854.

52. Shull MM, Ormsby I, Kier AB, Pawlowski S, Diebold RJ, Yin M, Allen R, Sidman C, Proetzel G, Calvin D, et al. Targeted disruption of the mouse transforming growth factor- $\beta 1$ gene results in multifocal inflammatory disease. Nature 1992;359:693-699.

53. Kulkarni AB, Huh CG, Becker D, Geiser A, Lyght M, Flanders KC, Roberts AB, Sporn MB, Ward JM, Karlsson S. Transforming growth factor $\beta 1$ null mutation in mice causes excessive inflammatory response and early death. Proc Natl Acad Sci USA 1993;90:770-774.

54. Dang H, Geiser AG, Letterio JJ, Nakabayashi T, Kong L, Fernandes G, Talal N. SLE-like autoantibodies and Sjogren's syndrome-like symphoproliferation in TGF- $\beta$ knockout mice. J Immunol 1995; 155:32053212

55. Crowe MJ, Doetschman T, Greenhalgh DG. Delayed wound healing in immunodeficient TGF- $\beta 1$ knockout mice. J Invest Dermatol 2000;115:3-11.

56. Geiser AG, Zeng QQ, Sato M, Helvering LM, Hirano T, Turner CH Decreased bone mass and bone elasticity in mice lacking the transforming growth factor- $\beta 1$ gene. Bone 1998;23:87-93.

57. Williams AO, Knapton AD, Geiser A, Letterio JJ, Roberts AB. The liver in transforming growth factor- $\beta 1$ (TGF- $\beta 1$ ) null mutant mice. Ultrastruct Pathol 1996;20:477-490.

58. Sanford LP, Ormsby I, Gittenberger-de Groot AC, Sariola H, Friedman R, Boivin GP, Cardell EL, Doetschman T. TGF- $\beta 2$ knockout mice have multiple developmental defects that are non-overlapping with other TGF- $\beta$ knockout phenotypes. Development 1997;124:2659-2670.

59. Saika S, Saika S, Liu CY, Azhar M, Sanford LP, Doetschman T, Gendron RL, Kao CW, Kao WW. TGF- $\beta 2$ in corneal morphogenesis during mouse embryonic development. Dev Biol 2001;240:419-432.

60. Kaartinen V, Voncken JW, Shuler C, Warburton D, Bu D, Heisterkamp N, Groffen J. Abnormal lung development and cleft palate in mice lacking TGF- $\beta 3$ indicates defects of epithelial-mesenchymal interaction. Nat Genet 1995;11:415-421.

61. Larsson J, Goumans MJ, Sjostrand LJ, van Rooijen MA, Ward D, Leveen $\mathrm{P}, \mathrm{Xu} \mathrm{X}$, ten Dijke P, Mummery CL, Karlsson S. Abnormal angiogenesis but intact hematopoietic potential TGF- $\beta$ type I receptor-deficient mice. EMBO J 2001;20:1663-1673.

62. Shida N, Ikeda H, Yoshimoto T, Oshima M, Taketo MM, Miyoshi I. Estrogen-induced tumorigenesis in the pituitary gland of TGF- $\beta \pm$ knockout mice. Biochim Biophys Acta 1998;407:79-83.

63. Borton AJ, Frederick JP, Datto MB, Wang XF, Weinstein RS. The loss of Smad3 results in a lower rate of bone formation and osteopenia through dysregulation of osteoblast differentiation and apoptosis. J Bone Miner Res 2001;16:1754-1764.
64. Ashcroft GS, Yang X, Glick AB, Weinstein M, Letterio JL, Mizel DE, Anzano M, Greenwell-Wild T, Wahl SM, Deng C, Roberts AB. Mice lacking Smad3 show accelerated wound healing and impaired . 1999;59:6113-6117.

65. Flanders KC, Sullivan CD, Fujii M, Sowers A, Anzano MA, Arabshahi A, Major C, Deng C, Russo A, Mitchell JB, Roberts AB. Mice lacking Smad3 are protected against cutaneous injury induced by ionizing radiation. Am J Pathol 2002;160:1057-68.

66. Takaku K, Miyoshi H, Matsunaga A, Oshima M, Sasaki N, Taket MM. Gastric and duodenal polyps in Smad4 (Dpc4) knockout mice. Cancer Res 1999;59:6113-7.

67. Roberts AB, Sporn MB. Transforming growth factor- $\beta$. In: Clark RAF, editor. The Molecular and Cellular Biology of Wound Repair. New York:Plenum Press; 1996, p. 275-308.

68. Robson MC, Phillip LG, Cooper DM, Lyle WG, Robson LE, Odom L, Hill DP, Pharm D, Hanham AF, Ksander GA. Safety and effect of transforming growth factor- $\beta 2$ for treatment of venous stasis ulcers. Wound Rep Reg 1995;3:157-167.

69. Hirshberg J, Coleman J, Marchant B, Rees RS. TGF- $\beta 3$ in the treatment of pressure ulcers: a preliminary report. Adv Skin Wound Care 2001;14:91-95.

70. Sonis ST, Lindquist L, Van Vugt A, Stewart AA, Stam, K, Qu GY, Iwata KK, Haley JD. Prevention of chemotherapy-induced ulcerative mucositis by transforming growth factor- $\beta 3$. Cancer Res 1994;54:1135-1138.

71. Foncuberta MC, Cagnoni PJ, Brandts CH, Mandanas R, Fields K, Derigs HG, Reed E, Sonis ST, Fay J, LeVeque F, Pouillart P, Schrezenmeier $\mathrm{H}$, Emmonds R, Thiel E. Topical transforming growth factor- $\beta 3$ in the prevention or alleviation of chemotherapy-induced oral mucositis in patients with lymphomas or solid tumors. J Immunother 2001;24:384388.

72. Ruskin JD, Hardwick R, Buser D, Dahlin C, Schenk RK. Alveolar ridge repair in a canine model using rh TGF- $\beta 1$ with barrier membranes. Clin Oral Implants Res 2000;11:107-115.

73. Sumner DR, Turner TM, Urban RM, Leven RM, Hawkins M, Nichols $\mathrm{EH}, \mathrm{McPherson}$ JM, Galante JO. Locally delivered rhTGF- $\beta 2$ enhances bone ingrowth and bone regeneration at local and remote sites of skeletal injury. J Orthop Res 2001;19:85-94.

74. Flanders KC, Ren RF, Lippa CF. Transforming growth factor- $\beta$ s in neurodegenerative disease. Prog Neurobiol 1998;54:71-85.

75. Lefer AM, Tsao P, Aoki N, Palladino MA Jr. Mediation of cardioprotection by transforming growth factor- $\beta$. Science 1990;249:61-64.

76. Lefer AM, Ma XL, Weyrich AS, Scalia R. Mechanism of the cardioprotective effect of transforming growth factor- $\beta 1$ in feline myocardial ischemia and reperfusion. Proc Natl Acad Sci USA 1993;90:10181022.

77. Pang L, Ye W, Che XM, Roessler BJ, Betz AL, Yang GY. Reduction of inflammatory response in the mouse brain with adenoviral-mediated transforming growth factor-ss1 expression. Stroke 2001;32:544-552.

78. Racke M, Dhib-Jalbut S, Cannella B, Albert PS, Raine CS, McFarlin DE. Prevention and treatment of chronic relapsing experimental allergic encephalomyelitis by transforming growth factor- $\beta 1$. J Immunol 1991;146:3012-3017.

79. Thorbecke GJ, Shah R, Leu CH, Kuruvilla AP, Hardison AM, Palladino MA. Involvement of endogenous tumor necrosis factor alpha and transforming growth factor- $\beta$ during induction of collagen type II arthritis in mice. Proc Natl Acad Sci USA 1992;89:7375-7379.

80. Chen LZ, Hochwald GM, Huang C, Dakin G, Tao H, Cheng C, Simmons WJ, Dranoff G, Thorbecke GJ. Gene therapy in allergic encephalomyelitis using myelin basic protein-specific $T$ cells engineered to express latent transforming growth factor- $\beta 1$. Proc Natl Acad Sci USA 1998;95:12516-12521.

81. Kitani A, Fuss IJ, Nakamura K, Schwartz OM, Usui T, Strober W. Treatment of experimental (Trinitrobenzene sulfonic acid) colitis by intranasal administration of transforming growth factor-(TGF) $\beta 1$ plasmid: TGF- $\beta 1$-mediated suppression of T helper cell type 1 response occurs by interleukin (IL)-10 induction and IL-12 receptor $\beta 2$ chain down regulation. J Exp. Med 2000;192:41-52.

82. Suda T, D’Ovidio F, Daddi N, Ritter JH, Mohanakumar T, Patterson GA Recipient intramuscular gene transfer of active transforming growth factor- $\beta 1$ attenuates acute lung rejection. Ann Thorac Surg 2001;71:1651-1656

83. Border WA, Noble NA. Transforming growth factor $\beta$ in tissue fibrosis. N Engl J Med 1994;331:1286-92. 
84. Fakhrai H, Dorigo O, Shawler DL, Lin H, Mercola D, Black KL, Royston I, Sobol RE. Eradication of established intracranial rat gliomas by transforming growth factor $\beta$ antisense gene therapy. Proc Natl Acad Sci USA 1996;93:2909-2914.

85. Sakamoto T, Ueno H, Sonoda K, Hisatomi T, Shimizu K, Ohashi H, Inomata $\mathrm{H}$. Blockade of TGF- $\beta$ by in vivo gene transfer of a soluble TGF- $\beta$ type II receptor in the muscle inhibits corneal opacification, edema and angiogenesis. Gene Ther 2000;7:1915-1924.

86. Kolb M, Margetts PJ, Galt T, Sime PJ, Xing Z, Schmidt M, Gauldie J. Transient transgene expression of decorin in the lung reduces the fibrotic response to Bleomycin. Am J Respir Crit Care Med 2001;163:770-777.

87. Kosuga K, Tamai H, Ueda K, Hsu YS, Ono S, Tanaka S, Doi T, Myou- U W, Motohara S, Uehata H. Effectiveness of tranilast on restenosis after directional coronary atherectomy. Am Heart J 1997;134:712-718.

88. Hill C, Flyvbjerg A, Rasch R, Bak M, Logan A. Transforming growth factor- $\beta 2$ antibody attenuates fibrosis in the experimental diabetic rat kidney. J Endocrinol 2001;170:647-651.

89. Callahan JF, Burgess JL, Fornwald JA, Gaster LM, Harling JD, Harrington FP, Heer J, Kwon C, Lehr R, Mathur A, Olson BA, Weinstock J, Laping NJ. Identification of novel inhibitors of the transforming growth factor $\beta 1$ (TGF- $\beta 1$ ) Type 1 receptor (ALK5). J Med Chem 2002;45:999-1001.

90. Maggard M, Meng L, Ke B, Allen R, Devgan L, Imagawa DK. Antisense TGF- $\beta 2$ immunotherapy for hepatocellular carcinoma: Treatment in a rat tumor model. Ann Surg Oncol 2001;8:32-37.

91. Border WA, Okuda S, Languino LR, Sporn MB, Ruoslahti E. Suppression of experimental glomerulonephritis by antiserum against transforming growth factor $\beta 1$. Nature 1990;346:371-374.

92. Border WA, Noble NA, Yamamoto T, Harper JR, Yamaguchi Y, Pierschbacher MD, Ruoslahti E. Natural inhibitor of transforming growth factor- $\beta$ protects against scarring in experimental kidney disease. Nature 1992;360:361-364.

93. Isaka Y, Tsujie M, Ando Y, Nakamura H, Kaneda Y, Imai E, Hori M. Transforming growth factor- $\beta 1$ antisense oligodeoxynucleotides block interstitial fibrosis in unilateral ureteral obstruction. Kidney Int 2000;58:1885-1892.

94. Yata Y, Gotwals P, Koteliansky V, Rockey DC. Dose-dependent inhibition of hepatic fibrosis in mice by a TGF- $\beta$ soluble receptor: Implications for antifibrotic therapy. Hepatology 2002;35:1022-1030.

95. Ueno H, Sakamoto T, Nakamura T, Qi Z, Astuchi N, Takeshita A, A soluble transforming growth factor- $\beta$ receptor expressed in muscle prevents liver fibrogenesis and dysfunction in rats. Hum Gene Ther 2000;11:33-42.

96. Kingston PA, Sinha S, David A, Castro MG, Lowenstein PR, Heagerty AM. Adenovirus-mediated gene transfer of a secreted transforming growth factor- $\beta$ type II receptor inhibits luminal loss and constrictive remodeling after coronary angioplasty and enhances advertitial collagen deposition. Circulation 2001;104:2595-25601.

97. McCormick LL, Zhang Y, Tootell E, Gilliam AC. Anti-TGF- $\beta$ treatment prevents skin and lung fibrosis in murine sclerodermatous graft-versus-host disease: a model for human scleroderma. J Immunol 1999; 163:5693-5699.

98. Logan A, Baird A, Berry M. Decorin attenuates gliotic scar formation in the rat cerebral hemisphere. Exp Neurol 1999;159:504-510.

99. Moon LD, Fawcett JW. Reduction in CNS scar formation without concomitant increase in axon regeneration following treatment of adult rat brain with a combination of antibodies to TGF- $\beta 1$ and $\beta 2$. Eur $\mathrm{J}$ Neurosci 2001;14:1667-1677.

100. Zheng H, Wang J, Koteliansky VE, Gotwals PJ, Hauer-Jensen M. Recombinant soluble transforming growth factor- $\beta$ type II receptor ameliorates radiation enteropathy in mice. Gastroenterology 2000;119:1286-1296.

101. Spearman M, Taylor WR, Greenberg AH, Wright JA. Antisense oligodeoxyribonucleotide inhibition of TGF- $\beta 1$ gene expression and alterations in the growth and malignant properties of mouse fibrosarcoma cells. Gene 1994;149:25-29.

102. Hoefer M, Anderer FA. Anti-(transforming growth factor- $\beta$ ) antibodies with predefined specificity inhibit metastasis of highly tumorigenic human xenotransplants in nu/nu mice. Cancer Immunol Immunother 1995;41:302-308.

103. Stander M, Naumann U, Dumitrescu L, Heneka M, Loschmann P, Gulbins E, Dichgans J, Weller M. Decorin gene transfer-mediated suppression of TGF- $\beta$ synthesis abrogates experimental malignant glioma growth in vivo. Gene Ther 1998;5:1187-1194.
104. Platten M, Wild-Bode C, Wick W, Leitlein J, Dichgans J, Weller M. N[3,4-dimethoxycinnamoyl]-anthranilic acid (tranilast) inhibits transforming growth factor- $\beta$ releases and reduces migration and invasiveness of human malignant glioma cells. Int J Cancer 2001;93:53-61.

105. Fakhrai H, Mantil J, Liu L, Nicholson G, Satter CM, Ruppert J, Krause G, Saadatmandi N, Shawler DL. Treatment of glioma with a TGF $\beta$ antisense-modified tumor cell vaccine. Proc Am Assoc Cancer Res $93^{\text {rd }}$ Annual Mtg. San Francisco, CA, April 6-10, 2002, Abst 714.

106. Wakefield LM, Roberts AB. TGF-beta signaling: positive and negative effects on tumorigenesis. Curr Opin Genet Dev 2002;12:22-29.

107. Calabresi PA, Fields NS, Maloni HW, Hanham A, Carlino J., Moore J, Levin MC, Dhib-Jalbut S, Tranquill LR, Austin H, McFarland HF, Racke MK. Phase 1 trial of transforming growth factor beta 2 in chronic progressive MS. Neurology 1998;51:289-292.

108. Wakefield LM, Winokur TS, Hollands RS, Christopherson K, Levinson $\mathrm{AD}$, Sporn MB. Recombinant latent transforming growth factor beta 1 has a longer plasma half-life in rats than active transforming growth factor beta 1, and a different tissue distribution. J Clin Invest 1990;86:1976-1984.

109. Schimid P, Itin P, Cox D. Proteolytic inactivation of transforming growth factor beta 3 by elastase in venous leg ulcers: implications for clinical trials using topically-applied peptide growth factors. Br J Dermatol 1999; 140:1170-2.

110. Blobe GC, Schiemann WP, Lodish HF. Role of transforming growth factor beta in human disease. N Eng J Med 2000;342:1350-8. 